\title{
Study on the Employability of International Business Graduates
}

\author{
Ning Liu \\ Dept. of Business Administration \\ Yunnan University of Finance and Economics \\ Kunming, China \\ 791939667@qq.com
}

\author{
Honglie Zhang* \\ Dept. of International Exchange and Cooperation \\ Yunnan University of Finance and Economics \\ Kunming, China \\ yufehelen@126.com
}

\begin{abstract}
How to improve the vocational skills of international business graduates has become a thorny issue in universities in the context of rising trade protectionism. By comparing and analyzing the training programs of international business professionals from 36 universities in China, the study summarizes the employability of international business graduates, which contains five aspects: international business skills, basic competencies in international business, professional comprehensive quality, awareness of improving self-competence, innovation capability of international business. Based on the current situation of international business professional education, the study puts forward four measures to enhance the employability of international business graduates: Relying on the Foreign Trade Park to build an integrated international business personnel training system of PSEUR (policy, student, enterprise, university, research institution); Subdivide the employable capabilities of international business graduates; Make full use of the emerging information technologies to improve the efficiency of international business graduate employability training; Optimize the curriculum of international business major and improve the efficiency in teaching. These recommendations will contribute to the improvement of the University's international business talent development program.
\end{abstract}

Keywords: employability, international Business, graduates

\section{INTRODUCTION}

Recently, although international free trade has been challenged by artificial trade frictions, trade between countries along the route is becoming more frequently in the context of the Belt and Road Initiative. It is vital to enhance the employability of international business graduates. Because the economic driving force of resources seeking optimal allocation remains unchanged, the development of international trade markets is unstoppable. Facing the volatile international business environment, international trade practitioners (international business graduates) must be equipped with higher professional skills and qualities. The massive expansion of higher education in China has led to questions about the quality of graduates in the labor market and their ability to meet employers' requirements [1]. Therefore, although foreign trade-oriented enterprises are very short of staff, there are still a large number of international business graduates unemployed

The practical significance of studying employable ability lies in improving the efficiency of human resources training.
As the demand for talent-to-hire capacity in different industries always change at any time, the general talent ability analysis method cannot meet the requirements of professional human resources management. We can effectively analyze the actual needs of the employable capacity system by combining with industry-specific human resources employable capacity requirements standards. As a national and social talent training institution, colleges and universities play a dominant role in cultivating college students' employability. The knowledge, skills, and conducts that students receive during school are largely influenced by the characteristics of a university and the system of training talents [2]. Therefore, the employability of graduates will be determined by the scientific and reasonable talent training program in colleges and universities. This study collects and analyzes the talent training programs of international business in 36 Chinese universities, combines similar items, summarizes the competence training content accepted by Chinese international business graduates, and refines the employable ability of Chinese international business graduates from the perspective of talent supply.

\section{TheORETICAL REVIEW}

Research on employability was launched at the beginning of the 20th century in Britain, where the industrial revolution was booming. The British scholar Beveridge proposed the "employability" and "employable" in 1909. Beveridge attributed unemployment to the employability of the workforce not to meet working standards [3]. The study of employability has gone through the process of "definition interpretation, system construction and practical". As a matter of fact, employability is a set of achievements of skills, understandings and personal attributes-that make graduates more likely to gain employment and be successful in their chosen occupations, which benefits themselves, the workforce, the community and the economy [4]. Three significant themes emerged out of the past research, each one focusing on different components of graduate employability: Business Specific Issues (business, related knowledge and skills), Interpersonal Competencies, Work Experience and Work, Based Learning [5]. The previous studies have focused on explaining what employability is and how to measure it, and rarely looking at how to improve a labor's employability. Based on cognitive and social psychology, Peter T Knight \& Mant Z Yorke co-authored the USEM employment theory model: professional understanding

*Corresponding author 
(knowledge), skills (including key skills), self-efficacy (including the sense of self-development), meta-cognitive (including the ability to learn how to learn) [6].

The researchers have put forward different solutions to analyze and explain employability. But most of them are normative analysis based on individual subjective empirical judgment and the conclusion is generally what graduates should or should not do. Although individual employability can be obtained from multiple platforms, university professional education is the main source for international business graduates. Independent competence and sound personality are two equally important goals in the talents cultivation in universities. In essence, the employability is a "threshold" index system that measures the value of human resources and reflects the employer's minimum requirements.

\section{WHAT INTERNATIONAL BUSINESS GRADUATES HAVE LEARNED?}

According to 2018 statistics, a total of 149 undergraduate colleges and universities opened international business majors in China. In order to obtain the content of international business students, the study collects the international business professional training programs of 36 colleges and universities, compares the specific content, analyzes the ability of talent training goals and talent specification requirements then summarizes the educational content received by international business students in Chinese universities. As the main source of labor market talent is university graduates, the educational content received by international business students is equivalent to their employability.

At the same time, colleges and universities take serving the local regional economic and social development as their mission, then the talent specification standards in their talent training programs are closely related to the regional economic structure. In spite of this, international business graduates must have common professional skills in the integrated market. By comparing and analyzing the international business professional training programs of 36 colleges and universities and merging the similar items, the study summarizes the content of the employable ability of international business graduates, which includes 29 items (see Table I).

Not all 29 items of competence in the table I are included in every talent development programs of the 36 colleges and universities, for example, some colleges and universities do not require students to "develop their own potential and constantly pursue progress". In the table I, the number refers to the times that competence items appear in 36 talent development programs, and frequency refers to the proportion of this competence item in all competence requirements. Most papers try to split employability into several categories before defining what is included in the term. Employability can be split as skills and knowledge, without the personal aspect [7]. Some skills are more commonly cited than others, like communication, team working, information technology and planning and organizing. The personal attributes that occur most often in research on employment include flexibility, adaptability, hardworking, commitment and dedication [8].
TABLE I. EMPLOYABILITY FOR INTERNATIONAL BUSINESS GRADUATES IN CHINA ${ }^{A}$

\begin{tabular}{|c|c|c|}
\hline $\begin{array}{c}\text { Serial } \\
\text { number }\end{array}$ & Competence items & $\begin{array}{l}\text { Number } \\
\text { (Frequency) }\end{array}$ \\
\hline Q1 & $\begin{array}{l}\text { customs declaration, commodity } \\
\text { inspection and customs clearance }\end{array}$ & $36(100.00 \%)$ \\
\hline Q2 & International payment and settlement & $36(100.00 \%)$ \\
\hline Q3 & $\begin{array}{l}\text { Classification of import and export } \\
\text { commodities and cross-border } \\
\text { logistics, commissioned transport }\end{array}$ & $36(100.00 \%)$ \\
\hline Q4 & Management of bills and certificates & $36(100.00 \%)$ \\
\hline Q5 & Accounting for quotes and deal risks & $36(100.00 \%)$ \\
\hline Q6 & $\begin{array}{l}\text { Ability to use foreign languages for } \\
\text { business activities }\end{array}$ & $36(100.00 \%)$ \\
\hline Q7 & $\begin{array}{l}\text { Mastering and applying the laws and } \\
\text { regulations of international markets }\end{array}$ & $36(100.00 \%)$ \\
\hline Q8 & Personal character and work ethic & $36(100.00 \%)$ \\
\hline Q9 & Professional recognition & $36(100.00 \%)$ \\
\hline Q10 & $\begin{array}{l}\text { Common sense and manners of } \\
\text { business etiquette }\end{array}$ & $36(100.00 \%)$ \\
\hline Q11 & Professional loyalty & $36(100.00 \%)$ \\
\hline Q12 & $\begin{array}{l}\text { Actively independently track ingress } \\
\text { with industry dynamics }\end{array}$ & $36(100.00 \%)$ \\
\hline Q13 & International marketing capabilities & $35(97.22 \%)$ \\
\hline Q14 & Career and sense of responsibility & $35(97.22 \%)$ \\
\hline Q15 & $\begin{array}{l}\text { Actively and effectively learn new } \\
\text { knowledge and technologies }\end{array}$ & $35(97.22 \%)$ \\
\hline Q16 & $\begin{array}{l}\text { Be familiar with the trend of changes } \\
\text { in international trade policy }\end{array}$ & $35(97.22 \%)$ \\
\hline Q17 & $\begin{array}{l}\text { International business consulting, } \\
\text { agents and other cross-border e- } \\
\text { commerce business }\end{array}$ & $34(94.44 \%)$ \\
\hline Q18 & $\begin{array}{l}\text { Cross-cultural communication, } \\
\text { collaboration and organizational } \\
\text { management capabilities }\end{array}$ & $34(94.44 \%)$ \\
\hline Q19 & Reasonable career planning & $34(94.44 \%)$ \\
\hline Q20 & $\begin{array}{l}\text { Explore new ways of trade based on } \\
\text { the Belt and Road Initiative }\end{array}$ & $34(94.44 \%)$ \\
\hline Q21 & $\begin{array}{l}\text { The ability to use network } \\
\text { information technology in the foreign } \\
\text { trade environment }\end{array}$ & $33(91.67 \%)$ \\
\hline Q22 & Regulate and control your emotions & $33(91.67 \%)$ \\
\hline Q23 & $\begin{array}{l}\text { International business negotiation and } \\
\text { cooperation capabilities }\end{array}$ & $32(88.89 \%)$ \\
\hline Q24 & Good health and mentality & $32(88.89 \%)$ \\
\hline Q25 & $\begin{array}{l}\text { Recognize and apply new trade } \\
\text { models based on cross-border e- } \\
\text { commerce }\end{array}$ & $32(88.89 \%)$ \\
\hline Q26 & $\begin{array}{l}\text { Customer data Integration and } \\
\text { analysis capabilities in international } \\
\text { markets }\end{array}$ & $31(86.11 \%)$ \\
\hline Q27 & $\begin{array}{l}\text { Develop your potentiality } \\
\text { spontaneously, pursue progress } \\
\text { constantly }\end{array}$ & $31(86.11 \%)$ \\
\hline Q28 & $\begin{array}{l}\text { Fine foreign trade market operation } \\
\text { and management based on data }\end{array}$ & $28(77.78 \%)$ \\
\hline Q29 & $\begin{array}{l}\text { Positive personal development } \\
\text { attitude }\end{array}$ & $27(75.00 \%)$ \\
\hline
\end{tabular}

a. Data from 36 colleges and universities international business professional talent training program 


\section{WHAT IS THE EMPLOYABILITY STRUCTURE OF INTERNATIONAL BUSINESS GRADUATES?}

The research value of employable ability lies in improving the matching degree of professional supply and demand by analyzing the needs of both supply and demand in specific industries. To answer the question from the title more accurately, a survey of human resource managers, foreign trade business executives and foreign-related market business practitioners in foreign trade-oriented companies was designed for this study. The questionnaire consists of 30 questions which are converted from 29 items in Table I and the last question is "please score the usefulness of what you have learned to your work". The answer is using the Likert scale (based on a 5-point Likert scale), which uses the numbers " $1-5$ " to refer to "Totally inconsistent", "Inconsistent", "Indecisive", "Consistent" and "Totally consistent". A total of 420 questionnaires were distributed and 403 questionnaires were recovered, with an effective rate of $95.95 \%$.

\section{A. What is the employability structure of international business graduates?}

Based on the questionnaire data, this study adopts Exploratory Factor Analysis to explore the employability structure of international business graduates. As shown in the table II, the KMO statistic is .887>0.7, and the effect of factor analysis is relatively good. The Bartlett spherical test shows that the independence hypothesis of each variable is not valid, so the applicability test of factor analysis is passed.

\section{TABLE II. KMO AND B ARTLETT's TEST B}

\begin{tabular}{llr} 
Kaiser-Meyer-Olkin Measure of Sampling Adequacy. & .887 \\
\hline Bartlett's Test of Sphericity & Approx. Chi-Square & 4383.077 \\
\cline { 2 - 3 } & df & 406 \\
\cline { 2 - 3 } & Sig. & .000 \\
\hline
\end{tabular}

Through principal component analyzing, I take the eigenvalue $>1$ as the initial factors then 5 factors are extracted. The explanatory power of 5 factors is $54.631 \%$ so the factor analysis effect is acceptable. In order to reflect the attribution relationship between original variables, the data structure is simplified after matrix rotation converged in 6 iterations (table III).

By comparing the contents of the items that are converged by the 5 factors, the study summarizes the five components of the employability of international business graduates (table IV): (1) Professional comprehensive quality; It specifically refers to personal character and work ethic, common sense and manners of business etiquette, professional loyalty etc. (2) Basic capability in international business; It is mainly the ability to use foreign languages for business activities, mastering and applying the laws and regulations of international markets, cross-cultural communication, collaboration and organizational management capabilities etc. (3)International business skills; It includes customs declaration commodity inspection and customs clearance, international payment and settlement, management of bills and certificates etc. (4) Awareness of improving self-competence;

TABLE III. ROTATED COMPONENT MATRIX C

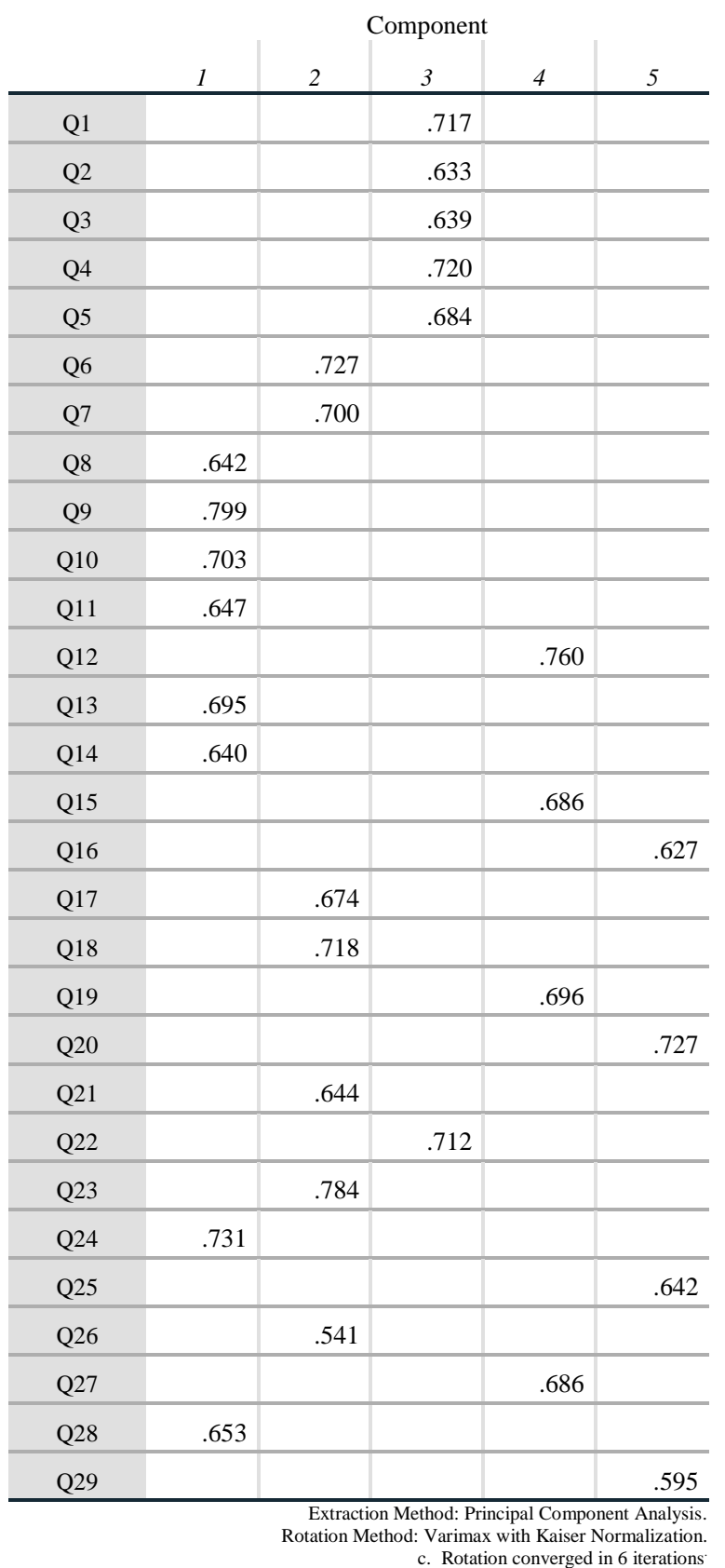

It contains the awareness of developing your potentiality spontaneously, pursuing progress constantly, learning new knowledge and technologies actively and effectively etc. (5) Innovation capability of international business; It involves in exploring new ways of trade based on the Belt and Road Initiative, recognizing and apply new trade models based on cross-border e-commerce etc. These capabilities are designed to enable international business graduates to cope with the rapidly changing foreign trade market environment and target customer needs. 
The five components on the employability of international business graduates are extracted from the talent training programs of 36 universities in the perspective of talent supplying. Do these competencies acquired on campus meet the needs of specific work?

TABLE IV. KMO AND BARTLETT'S TEST D

\begin{tabular}{|c|c|c|c|c|}
\hline \multirow{2}{*}{ Competencies } & \multirow{2}{*}{$\begin{array}{l}\text { Item } \\
\mathbf{s}\end{array}$} & \multicolumn{2}{|c|}{ Mean $Q_{i}$} & \multirow{2}{*}{ Mean $C_{(i}$} \\
\hline & & Statistic & Std. Error & \\
\hline \multirow{8}{*}{$\begin{array}{l}\text { (1) Professional } \\
\text { comprehensive quality }\end{array}$} & Q8 & 2.63 & 0.054 & \multirow{8}{*}{2.63} \\
\hline & Q9 & 3.23 & 0.051 & \\
\hline & Q10 & 2.85 & 0.056 & \\
\hline & Q11 & 3.49 & 0.048 & \\
\hline & Q13 & 3.20 & 0.052 & \\
\hline & Q14 & 2.92 & 0.051 & \\
\hline & Q24 & 3.04 & 0.052 & \\
\hline & Q28 & 3.15 & 0.052 & \\
\hline \multirow{7}{*}{$\begin{array}{l}\text { (2) Basic capabilities in } \\
\text { international business }\end{array}$} & Q6 & 3.11 & 0.059 & \multirow{7}{*}{3.11} \\
\hline & Q7 & 3.70 & 0.05 & \\
\hline & Q17 & 3.00 & 0.055 & \\
\hline & Q18 & 3.37 & 0.059 & \\
\hline & Q21 & 2.96 & 0.052 & \\
\hline & Q23 & 3.29 & 0.051 & \\
\hline & Q26 & 3.54 & 0.051 & \\
\hline \multirow{6}{*}{$\begin{array}{l}\text { (3) International business } \\
\text { skills }\end{array}$} & Q1 & 2.07 & 0.046 & \multirow{6}{*}{2.07} \\
\hline & Q2 & 2.39 & 0.047 & \\
\hline & Q3 & 2.28 & 0.047 & \\
\hline & Q4 & 2.25 & 0.046 & \\
\hline & Q5 & 2.15 & 0.042 & \\
\hline & Q22 & 2.15 & 0.042 & \\
\hline \multirow{4}{*}{$\begin{array}{l}\text { (4) Awareness of improving } \\
\text { self-competence }\end{array}$} & Q12 & 2.13 & 0.056 & \multirow{4}{*}{2.13} \\
\hline & Q15 & 2.96 & 0.06 & \\
\hline & Q19 & 2.18 & 0.052 & \\
\hline & Q27 & 2.41 & 0.056 & \\
\hline \multirow{4}{*}{$\begin{array}{l}\text { (5) Innovation capability of } \\
\text { international business }\end{array}$} & Q16 & 2.25 & 0.043 & \multirow{4}{*}{2.25} \\
\hline & Q20 & 2.20 & 0.043 & \\
\hline & Q25 & 2.20 & 0.041 & \\
\hline & Q29 & 2.50 & 0.047 & \\
\hline $\begin{array}{l}\text { please score the usefulness of } \\
\text { what you have learned to } \\
\text { your work }\end{array}$ & Q30 & 1.20 & 0.021 & 1.20 \\
\hline
\end{tabular}

B. Are international business graduates qualified for specific jobs?

As shown in Table IV above, the 5 competencies' mean (Mean C (i ) ) are 2.63, 3.11, 2.07, 2.13, 2.25. The information reflects the practicality of the international business professional training program in colleges and universities. It also reflects the consistency between the teaching content designed by the talent training program and the competencies. Although the mean of each competency is not high, it is acceptable for Mean C (i) >2. But when it comes to how to evaluate the usefulness of the expertise you have learned in university; the average scores are only 1.20 (table IV). Since the minimum score is 1 , it is a very low assessment and means that the international business education is almost useless for practical job requirements. Many respondents believe that international business graduates are barely able to do the actual job on their own, and worse off, they are reluctant to work hard.

Instead of mechanically engaging in cross-border business, international business graduates ought to seek ways to explore international markets and promote trade development. In view of this phenomenon, we must reflect on the practicality of international business professional education.

\section{PROPOSALS TO ENHANCE THE EMPLOYABILITY OF INTERNATIONAL BUSINESS GRADUATES}

At present, the training mode of international business majors in Chinese universities is "professional + foreign language + skills + entrepreneurial quality" and the goal of ability training is strengthening the professional foundation, broadening the field of knowledge, focusing on the application of knowledge and improving practical skills. This article explores how international business professionals can be fostered by the higher education institution. For the international business education of colleges and universities, two problems need to be solved: what expertise to teach and how to carry out professional teaching activities? The design of teaching and learning for employability needs to offer an experience for students which allows them to see their employability as part of their core activities in higher education.

\section{A. Relying on the Foreign Trade Park to build an integrated international business personnel training system of PSEUR.}

The PSEUR is an innovative and efficient talent training program. PSEUR means policy, student, enterprise, university, research institution. International trade must be guided by the relevant national policies, so practitioners can't change it only by adapting to it. Students are the link between universities, enterprise and research institutions. The main reason why enterprises cooperate with universities is that universities are the base of talent supply. In the process of cooperation between enterprises and research institutions, they not only realize the sharing of technology and information, but also share talents, and then jointly cultivate reserve talents. Therefore, universities should take the initiative to set up the PSEUR system and build an efficient platform for international business personnel training. It can give full play to the advantages of its own resources, fundamentally solve the problem of disconnect between school education and social demand, narrow the gap between the supply of university talents and the demand of social talents and enhance the ability of graduates to work. it is inappropriate to assume that students are highly employable on the basis of curricular provision alone: it may be a good harbinger but it is not an assurance of employability [9]. The 
demand of talent that can be employed in the international trade market is constantly changing. the PSEUR system can achieve the balance of employable ability in the dynamic process, so that the supply of talent capacity meets the demand of talent capacity.

\section{B. Subdivide the employable capabilities of international business graduates}

In fact, international commerce involves a wide range of business, which refers to the transnational business activities arising from the international trade and international investment. International trade includes goods, services and intellectual property transactions. The current hot-topic international investment mainly refers to international direct investment, including sole proprietorship, joint ventures and cooperative ventures. For students to be more specialized in a particular field of study, it is necessary to further segment the learning directions of international business, so as to improve their employability.

\section{Make full use of the emerging information technologies to improve the efficiency of international business students employability training}

Information technology can not only provide fast and timesensitive international market information, but also change the traditional teaching methods. Depending on the contents of Table I, the basic skills of international business graduates are customs declaration, commodity inspection and customs clearance, International payment and settlement, classification of import and export commodities and cross-border logistics, etc. These solidified business processes can be learned efficiently through the international business network information teaching platform. The prerequisite for international business innovation and practice is to know the real-time and effective international market information. Therefore, mastering network information technology will help to improve the employability of international business graduates.

\section{Optimize the curriculum of international business major and improve teaching efficiency}

For the international business courses content, building a teaching content system based on advantageous and characteristics industries will be able to enhance the employability of international business graduates more effectively, such as tea export trade, cross-border trade of flowers, etc. For the teaching methods, it is best to focus on practical teaching. Students undertaking work placements learn more from their placements if they reflect on their experience during their placement. Reflective practice is noted as a key capability in many professions [10]. The ultimate goal of optimizing professional curriculum is to enable students to do what they want to do in future.

\section{CONCLUSION}

In the supply-side perspective, this paper summarizes 5 items of employability from the 36 international business professional talent training programs. Then through a questionnaire survey of international business practitioners, the paper examines that whether 5 items of employability match with the actual work requirements by analyzing of questionnaire survey data. Most respondents who are engaged in international business agree that the university's talent development program meets the specific job requirements, but don't believe that professional education in university is useful for actual work. In response to this situation, four measures are proposed to improve international business professional education. As a matter of factor, the issue of student engagement in employability is therefore manifold. It depends on the effectiveness of programmed design, implementation and delivery which in turn depends on support and agreement from both management and academic staff [11]. The position taken in this study is that employability goes well beyond the simplistic notion of key skills, and is evidenced in the application of a mix of personal qualities and beliefs, understandings, skillful practices and the ability to reflect productively on experience.

While it is inappropriate to assume that students are highly employable on the basis of university provision alone: it may be a good harbinger, but it is not an assurance of employability. Employability derives from the ways in which the student learns from his or her experiences [6]. To provide students with internship opportunities and practical platform, The PSEUR is an effective way to train international business professionals. In general, employability includes two dimensions: capacity structure and ability level. Only when the supply capacity structure is matched with the demand and the ability level is up to the demanded standard, can international business graduates be employed.

\section{ACKNOWLEDGMENT}

Funding for research is provided by the Humanities and Social Sciences Research Project on Education Cooperation in Province-Schools of Yunnan Province: Research on the construction of Higher Education Radiation Centre of Yunnan for South Asia and Southeast Asia. No. SYSX201810. At the same time, we would like to thank our friends for taking the precious time to help us fill out the questionnaires and every interviewee. Thanks to the teachers for providing the literatures.

\section{REFERENCES}

[1] Glenda Kruss. Employment and employability: expectations of higher education responsiveness in South Africa[J]. Journal of Education Policy,2004,19(6)

[2] Jingjing Liu. Research on the Evaluation of Employment Quality and the Improvement of Employment Ability of College Students[A]. Institute of Management Science and Industrial Engineering. Proceedings of 2019 3rd International Conference on Economics, Management Engineering and Education Technology (ICEMEET 2019) [C]. Institute of Management Science and Industrial Engineering: Computer Science and Electronic Technology International Society,2019:4.

[3] Ling Ling. The Mechanism of Impact of Employee Training on Organizational Commitment and Resignation Tendency Research [D]. Southwest University of Finance and Economics, 2012.

[4] Mantz Yorke, Employability in higher education- what it is -what it is not, 2006 
[5] Jane Andrews, Helen Higson. Graduate Employability, 'Soft Skills' Versus 'Hard' Business Knowledge: A European Study[J]. Higher Education in Europe,2008,33(4) 411-422.

[6] Wang Dongxing. The way to improve the employability of college students based on the USEM model theory is analyzed in j. Journal of Shandong Province Agricultural Management Cadre College, 2013,30 (02): 92-94.

[7] R. N. Hull, Transition from student to employee: the necessary science and skills, in Addressing Global Environmental Security through Innovative Educational Curricula, Springer, 2009, pp. 75-81.

[8] A. Tymon, The student perspective on employability, Stud. High. Educ., vol. 38, no. 6, pp. 841-856, Aug. 2013.
[9] Caballero, C., Walker, A., \& Fuller-Tyszkiewicz, M. 2011. The Work Readiness Scale (WRS): Developing a measure to assess work readiness in college graduates. Journal of Teaching and Learning for Graduate Employability, 2(2), 41 - 54.

[10] Jollands, M, Boles, W and Peterson, J 2017, 'Developing students' employability in work placements', in 28th Annual Conference of the Australasian Association for Engineering Education (AAEE 2017) Order of Proceedings, Sydney, Australia, 10-13 December 2017, pp. 362-368.

[11] Yorke, M. 2006. Employability in higher education: what it is - what it is not. York: Higher Education Academy. 